\title{
Editorial
}

\section{LA INVESTIGACIÓN COMO COMPROMISO}

\author{
Saniel E. Lozano Alvarado \\ EDITOR ASOCIADO
}

La paulatina y progresiva afirmación de IN CRESCENDO en el contexto de las publicaciones dedicadas a la investigación nos reafirma en nuestra convicción de que no puede haber universidad ni docentes universitarios sin investigación. Es que no debemos ser simplemente "dictadores", expositores o animadores de clases o lecciones por brillante que sea nuestro desempeño. No basta con estar bien informados, actualizados y puestos al día con los últimos avances, logros y descubrimientos para inmediatamente transmitirlos a los demás. Desde luego que tal actitud es ya un evidente y encomiable logro, porque no se puede seguir abrevando en manuales anacrónicos o estar transmitiendo conocimientos obsoletos y extemporáneos. Necesitamos estar al día en nuestra especialidad y en contacto directo con el conocimiento actual y contemporáneo.

Repetimos, tal actitud es valiosa pero insuficiente, porque significa usar y usufructuar el sacrificio, aporte y dedicación de otros sin que nosotros pongamos nuestra parte. Significa que así solo somos agentes intermediarios, propagandistas o transmisores de lo que otros investigan, producen o descubren haciendo avanzar la ciencia y la cultura. Además, tal actitud necesariamente nos lleva a la dependencia, sometimiento y consumo de lo que otros producen y aportan, con lo cual tampoco podemos acceder a la libertad, pues, es como si necesitáramos de los demás para subsistir.

En cambio crear, investigar, producir, innovar y enseñar en las aulas es un claro signo de que también somos creadores y productores de ciencia, tecnología, cultura y humanidades. De esta manera, el docente universitario confronta lo que recibe, dialoga y propone como resultado de su quehacer intelectual, por lo que, al no depender de los demás, ejerce su rol de hombre libre y superior.

En el reconocimiento de esta realidad deben juzgarse las universidades y sus docentes. Y dentro de ella adquieren valor precisamente las revistas de investigaciones que se nutren de la ciencia y la cultura de sus autores, al mismo tiempo que se convierten en fructíferos puentes de diálogo por el fraterno encuentro con investigadores de otros espacios y procedencia. 
Es, por tanto, harto significativo, que IN CRESCENDO se esté consolidando con la regularidad, seriedad y rigor de su edición como revista de calidad ascendente y de periodicidad semestral; que se sustente en las investigaciones de sus autoridades, docentes y alumnos; y que también reciba los generosos aportes de investigadores y autores de otras universidades y centros académicos. Tal situación revela la consistente credibilidad y confianza que generamos en el conjunto universitario, educativo, social y regional.

Al mismo tiempo, nuestra presencia evidencia que vamos accediendo a la imagen de una universidad que no se limita a la formación meramente profesional de sus alumnos, sino que, por el aporte conjunto de los autores, vamos accediendo a un status más elevado, riguroso y trascendente, en la perspectiva de ser una corporación científica, tecnológica y humanística.

Por eso renovamos nuestro testimonio de gratitud a los autores que nos honran con sus trabajos. Varios de ellos vienen aportando desde números anteriores, mientras que otros se van incorporando progresivamente a esta gratificante tarea. Felicitaciones a todos. Por eso exhibimos y entregamos orgullosos este nuevo número de nuestra revista que lleva su mensaje afectuoso y fraterno a la comunidad local, regional, nacional e internacional. Al congratularlos nos ponemos también a la consideración de autores, investigadores, docentes y alumnos para las sugerencias o cuestionamientos que tengan a bien formularnos. 